\title{
KOMPETENSI INTERPERSONAL PADA ANAK PANTI ASUHAN DENGAN SISTEM PENGASUHAN TRADISIONAL DAN ANAK PANTI ASUHAN DENGAN SISTEM PENGASUHAN IBU ASUH
}

\author{
Rina Mulyati \\ Universitas Islam indonesia
}

INTISARI

Penelitian ini bertujuan untuk mengetahui apakah ada perbedaan tingkal kompetensi interper sonal antara anak-anak panf asuhan yang diasuh dengan sistem pengasuhan tradisional dan anak-anak panti asuhan yang diasuh dengan sistem pengasuhan ibu asuh.

Subjek yang dijadikan sampel pada penelitian ini sebanyak 80 anak (masinginasing sistem 40 anak) yang ada pada tahap perkernbangan kanak-kanak akhir (berusia sembilan sampai 12 tahun). masih sekolah di sekolah dasar dan tinggal sekurang-kurangnya selama salu tahun di panti asuhan yang menggunakan salah salu dari dua sistem pengasuhan yang telat disebutkan di at.as.

Alat ukur yang dipakai pada penelitian ini yang telah dinyatakan valio dan reliabel adalah: (a) angket persepsi fingkat demokratisasi pola asuh (koelisien valichas yang bergerak antara 0.266 sampai 0.596 dengan koefisien reliabilitas sebesar. 0 847) dan (b) angket kompetensi interpersonal (koefisien validitas bergerak antara 0.252 sampai 0.618 dengan koetisien reliabilitas sebesar. $0.884)$.

Dari hasil penelitian analisis data dengan analisis varians satu jalur diper oleh hasil peneiltian bahwa tidat ada perbedaan tingkat kompetensi interpersonal anak-anak yang diasuh dengan sistem pengasuhan tradisional dan antara anak-anak yang diasuh dengan sistem pengasuhan ibu asuh ( $F=1.837 ; p=$ 0.776). Dengan melihat rerala empirik $y$ ang lebih besar daripada rerata hipotelik, dapat disimpukan bahwa anak-anak pada kedua sistem pengasuhan memiliki tingkat kompetensi interpersonal yang sama tinggi (rerala hipotetik =2.25, rerata empirik sistem tradisional 35.625 dan sistem ibu asuh $=34.37 .5$ ).

Kata kunci: kompetensi interpersonal, sistem pengasuhan tradisional, sistem pengasuhan ibu asuh

Rina Mulyati, lahir of Garut (Jawa Barat), adalah dosen tetap Fakultas Psikologi UII Yogyakarta dan slat pada Biro Konsultasi Psikologi P.ARAHTA Yogyakarta. Memiliki minat $y$ ang besar pada masalah anak dan remaja

\section{PENGANTAR}

$P$ anti asuhan adaiah sebuah lembaga yang sangat populer untuk membantu perkembangan anak-anak yang tidak memiliki keluarga ataupun yang tidak dapat tinggal dengan keluarganya. Panti asuhan berperan sebagai pengganti keluarga dalam me- 
menuhi kebutuhan anak dalam proses perKembangannya. Panti asuhan umumnya memakai salah satu dari dua sistem pengasuhan dalam mendidik anak-anak asuhnya, yaitu sistem pengasuhan tradisional dan sistem pengasuhan ibu asuh. Kedua sistem pengasuhan tersebut memiliki perbedaan pada rasio anak dengan pengasuh. stabilitas dan kontinyuitas interaksi pengasuh dengan anak serta demokratisasi pola asuh pengasuh.

Pada sistem pengasuhan ibu asuh, ra sio anak dengan pengasuh kecil (10: 1), interaksi anak dengan pengasuh stabil dan kontinyu serta tingkat demokratisasi pola asuh pengasuh tinggi. Sedang pada sistem pengasuhan tradisional, rasio anak dengan pengasuh besar (20: 1), interaksi anak dengan pengasuh tidak stabil dan tidak kontinyu serta tingkat demokratisasi pola asuh pengasuh yang rendah.

Sistem pengasuhan tersebut. secara langsung maupun tidak langsung akan mempengaruhi perkembangan anak-anak asuhnya, yang meliputi perkembangan fisik, psikis dan sosial.

\section{TELAAH PUSTAKA}

Perkembangan yang paling menonjol pada anak-anak usia sekolah adalah perkembangan sosial karena pada masa ini anak mulai mengembangkan lingkup pergaulannya ke luar rumah, yaiłu ke lingkungan sosial yang lebih luas. Anak usia sekolah mulai memiliki sahabat dan hubungan yang sukses dengan teman sebaya dapat membantu menumbuhkan perasaan berarti pada anak dan meningkatkan rasa percaya diri.

Hubungan interpersonal yang etektif (seperti persahabatan), dapat terbina jika mereka memiliki kemampuan-kemampuan dalam membina hubungan interpersonal. $\mathrm{Ke}$ mampuan tersebut secara khusus oleh Buhrmester dkk (1988) disebut sebagai kompetensi interpersonal. Kompetensi interpersonal memiliki lima aspek, yaltu inisiatif, keterbukaan (self-disclosure), asertivitas, dukungan emosional (emotional support) dan pengatasan konflik.

Inisiatif yang merupakan aspek pertama dari kompetensi interpersonal, menurut Bee (1981) adalah kimampuan untuk memulai suatu bentuk usaha untuk mencapai suatu iujuan. Buhrmester dkk (1988) menyebutkan inisiatif sebagai usaha untuk memulai suatu bentuk interaksi dengan individu lain atau dengan tingkungan sosial yang lebih luas. Erickson (1978) mendeskripsikan inisiatif sebagai suatu usaha mencari informasi dan meneliti secara aktif terhadap lingkungannya. Dengan kemampuan berinisiatif, seseorang akan melakukan penjelajahan (eksplorasi), memulai suatu hubungan dan bergerak secara aktif dan mandiri.

Aspek kedua adalah keterbukaan (selfdisclosure) yang oleh Wrigtsman dan Deaux (1981) diartikan sebagai kemampuan untuk mengungkapkan informasi yang bersifat pribadi yang menurut Jourard (dalam Calhoun dan Acocella, 1990) dikatakan sebagai kemampuan untuk membicarakan diri sendiri. Keterbukaan ini dibutuhkan dalam hubungan interpersonal dan harus proporsional. Contohnya keterbukaan yang berlebihan of awal hubungan, menurut Wortman (dalam Grasha, 1987), akan menimbulkan kesan kurang dewasa, tidak bisa dipercaya dan tidak aman. Sedang jika dalam hubungan interpersonal tidak ada keterbukaan, maka hubungan yang terialin tidak akan memuaskan dan efektif. Dengan adanya keterbukaan, kebutuhan dua orang terpenuhi, yaitu dari tihak pertama kebuluhan untuk bercerita dan berbagai rasa terpenuhi sedang bagi fihak kedua dapat muncul perasaan istimewa karena dipercaya untuk mendengarkan cerita yang bersifat pribadi.

Aspek yang ketiga adalah asertivitas yang oleh Perlmian dan Cozby (1983) diarti- 
kan sebagai kemampuan untuk mengungkapkan perasaan-perasaan secara jelas dan mempertahankan hak-haknya secara tegas. Lange dan Jakubowsky (dalam Calhoun dan Acosella, 1990) menyatakan bahwa aserțvitas adalah kemampuan untuk mempertahankan hak-hak pribadi, mengemukakan gagasan, perasaan dan keyakinan secara langsung, jujur dan sesuai. Perilaku asertif yang paling sederhana adalah mampu mengatakan "fidak" jika diminta untuk melakukan sesuatu yang tidak disukai (Buhrmester dkk, 1988). Dengan memiliki sikap asertif, individu tidak akan diperlakukan secara tidak pantas oleh lingkungan sosialnya dan dianggap sebagai individu yang memiliki harga diri.

Dukungan emosional sebagai aspek keempa: dari kompetensi interpersonal didefinisikan oleh Jung (dalam Hill, 1991) sebagai pengekspresjan perhatian, rasa aman dan nyaman serta simpati. Shepard dan Voss (dalam Allen, 1980) menyebutnya dengan ekspresi efektif dan salah satu ekspresi efektif itu adalah empati. Dengan memiliki empati, seseorang lebih mampu memahami orang lain (Hoffman dalam Mussen dkk, 1979) dan dengan kemampuan ini seseorang akan lebih mudah melakukan penyesuaian diri ketika berinteraksi dengan orang lain. Selain empati, dukungan emosional juga meliputi aspek lain, yaitu sikap hangat. Menurut Barker dan Lemle (dalam Buhrmester dkk, 1988), sikap hangat ini dapat memberikan perasaan nyaman kepada orang lain dan akan sangat berarti ketika orang iersebut sedang dalam kondisi ter. tekan dan bermasalah.

Pengatasan konfik merupakan aspek yang terakhir dari kompetensi interpersonal. Konflik, menurut Grasha (1987), senantiasa hadir dalam setiap hubungan antar manusia dan bisa muncul karena berbagai sebab. Kemampuan mengatasi konflik dalam penelitian ini, menurut Buhrmester(1986), ada- lah berupaya agar konflik yang muncul dalam suatu hubungan interpersonal tidak semakin memanas. Kemampuan ini secara khusus akan sangat dibutuhkan oleh anakanak panti asuhan karena mereka tinggal dalam kelompok besar yang kemungkinan munculnya konflik sangat besar.

Kompetensi interpersonal pada masa anak dalam perkembangannya sangat dipengaruhi oleh pola interaksi anak dengan ibu. Pola interak.si ini meliputi cara pandang pengasuh terhadap anak. cara berkomu. nikasi, penerapan disiplin dan kontrol serta cara pemenuhan kebutuhan anak seharihari. Pola interaksi bu dengan anak tersebut, menurut Kohn (dalam Winarto, 1991). dapat dikatakan sebagai pola asuh.

Pola asuh yang dapat menumbuhkan kompetensi irterpersonal pada anak adalah pola asuh yang demokratis. Dalam pola asuh ini ibu menunjukkan sikap yang hangat, suportif. terbuka, ada komunikasi dua arah dan tidak menggunakan hukuman fisik dalam mendisiplinkan anak. Sikap terşebut dapat menumbuhkan rasa ingin tahu yang tinggi, mudah bergaul, spontan dan asertif. Sikap-sikap yang disebutkan di afas adalah ciri-ciri dimilikinya kompetensi interpersonal padaanak.

Pengasuh sebagai ibu pengganti bagi anak-anak panti asuhan akan memiliki pola sikap tertentu yang berbeda pada setiap pengasuh ketika mereka berinferaksi dengan anak-anak asuh. Pada sistem pengasuhan ibu assuh, pola asuh pengasuh lebih demokratis dibandingkan dengan pola asuh pengasuh pada sistem pengasuhan tradisional sehingga anak-anak asuhnya akan memiliki sikap-sikap seperti rasa ingin tahu yang tinggi, mudah bergaul, spontan dan asertif.

Selain pola asuh pengasuh, ternyata stabilitas dan kontinyuitas interaksi anak dengan pengasuh dapat mempengaruhi perkembangan kompetensi interpersonal anak. 
Menurut Dennis (dalam Newman dan Newman, 1979), anak yang memiliki pengasuh yang tidak stabil dan tidak kontinyu cenderung mengalami hambatan dalam proses penyesuaian diri dan tidak mampu melibatkan aspek emosi ketika berinteraksi dengan orang lain. Anak-anak sistem pengasuhan ibu asuh berinteraksi dengan pengasuhnya secara stabil dan kontinyu, berarti proses penyesuaian diri anak dan kemampuan anak untuk melibatkan aspek emosi ketika berinteraksi dengan lingkungan sosialnya akan lebih baik.

Faktor lain yang dapat mempengaruhi perkembangan anak di panti asuhan adalah rasio anak dengan pengasuh, semakin kecil rasio semakin kecil kemungkinan terjadinya hambatan dalam perkembangan anak. Anak-anak panti asuhan dengan sistem pengasuhan ibu asuh berinteraksi dengan pengasuh secara stabil dan kontinyu serta rasio anak dengan pengasuh relatif lebih kecil dibandingkan anak-anak pada sistem pengasuhan tradisional.

\section{HIPOTESIS}

Berdasarkan uraian teoritik di atas, maka hipotesis yang diajukan pada penelitian ini adalah:

Ada perbedaan tingkat kompetensi interpersonal antara anak-anak panti asuhan dengan sistem pengasuhan tradisional dengan anak-anak panti asuhan dengan sistem pengasuhan ibu asuh. Anak-anak pada sistem pengasuhan ibu asuh akan memiliki tingkat kompetensi interpersonal yang lebih tinggi dibandingkan dengan anak-anak pada sistem pengasuhan tradisional.

\section{METODE}

Dalam penelitian ini sebagai variabel be basnya adalah sistem pengasuhan panti asuhan dan variabel tergantungnya adalah tingkat kompetensi interpersonal anak.
Populasi penelitian ini adalah anak-anak panti asuhan yang berada pada fase kanakkanak akhir ( 9 - 12 tahun), sedang menjalani pendidikannya di sekolah dasar dan telah tinggal d panti asuhan dengan salah satu dari dua sistem pengasuhan sekurang-kurangnya selama satu tahun pada saat penelitian diłaksanakan.

Sampel penelitian ini adalah anak-anak Panti Asuhan Muhammadiyah Putri (Yogyakarta). Panti Asuhan Tanah Putih. Panti Asuhan Gatot Subroto dan SOS Kinderdort Masing-masing subjek diminta untuk mengisi angket persepsi demokratisasi pola asuh pengasuh dan angket kompetensi in terpersonal.

\section{a. Angket Persepsi Demokratisasi Pola Asuh Pengasuh}

Angket ini merupakan hasil adaplaș dari angket demokratisasi pola asuh orang tua (Winarto, 1988) yang terdiri dari 32 sistem. Setelah diujicobakan pada 40 subjek ternyata aitem yang valid ada 22 butir dengan koefisien validitas yang bergerak antara 0.226 sampai dengan 0.596 dan koefisien reliabilitas sebesar 0.847 .

Aitem pada angket tersebut memiliki tiga alternatif jawaban, setiap alternatif jawaban mewakili satu pola asuh (demokratis. permisif dan otoriter). Setiap jawaban yang memilih pola asuh demokratis dinifai satu sedang pilihan yang lain dinilai nol.

\section{b. Angket Kompetensi Interpersonal}

Aitem-aitem pada angket kompetensi interpersonal disusun mengacu pada dasar teori mengenai kompetensi interpersonal. Angket pertama dianggap tidak memenuhi syarat sehingga perlu disempurnakan. Penyempurnaan dilakukan dengan mengubah struktur kalimal pernyataan menjiadi pertanyaan. Angket yang telah disempurnakan 
tersebut memiliki 61 aitem yang mana setelah dilakukan uji coba aitem yang dinyatakan valid ada 45 butir dengan koefisien validitas yang bergerak antara 0.226 sampai 0.572 . Aitem-aitem yang dinyatakan valid kemudian diuji reliabilitasnya yang menghasilkan koefisien reliabilitas sebesar 0.884 .

Aitem pada angket tersebut terdiri dari aitem yang favorabledan unlavorabledan setiap aitem pada angket ini memiliki dua altematif jaw aban. Setiap jawaban "ya" untuk aitem favorable mendapat nilai satu dan jawaban "tidak" mendapat nilai nol. Sedang untuk aitem unfavorable, setiap jawaban "tidak" mendapat nilai satu dan jawaban "ya" mendapat nilai nol.

Data yang terkumpul dari angke: demokratisasi pola asuh pengasuh dianalisis dengan menggunakan uji-t. Sedang untuk data yang diperoleh dari skor angket kompetensi interpersonal dianalisis dengan menggunakan analisis varians satu jalur.

\section{HASIL}

Dari penelitian ini didapatkan hasil yang berupa nilal $F$ sebesar 1.837 dengan $p=$ $0.176)$. Hal ini menunijukkan bahwa tidak ada perbedaan tingkat kompetensi interpersonal antara anak-anak yang diasuh dengan sislem pengasuhan tradisional dengan anak yang diașuh dengan sistem pengasuhan ibu asuh. Walaupun demikian, dengan meliha: perbandingan rerata hipotetik dengan rerata empirik diperoleh hasil bahwa rerata empirik (sistem tradisional sebesar 35.625 dan sistem ibu asuh sebesar 34.375) lebih besar dibandingkan rerata hipotetik (sebesar 22.5) berarti tingkat kompetensi interpersonal anak-anak pada dua sistem pengasuhan tersebut termasuk tinggi.

\section{PEMBAHASAN}

Koefisien determinasi $\left(\mathrm{R}^{2}\right)$ sebesar 0.023 menunjukkan bahwa faktor perbedaan rasio anak dengan pengasuh, stabilitas dan kontinyuitas interaksi pengasuh dengan anak dan tingkat demokratisasi pola asuh pengasuh ternyata hanya memberikan sumbangan sebesar $0.23 \%$ untuk perkembangan tingkat kompetensi anak-anak panti asuhan pada penelitian ini. Dengan demikian dapat disimpulkan bahwa faktor sistem pengasuhan memberikan sumbangan yang tidak terlalu besar terhadap kompetensi interpersonal anak. Banyak faktor lain yang dimungkinkan lebih berpengaruh terhadap perkembangan tingkat kompetensi interpersonal anak, antara lain kondisi pengasuh, kesempatan berinteraksi dengan teman sebaya dan orang dewasa lain selain pengasuh dan karakteristik individual anak.

Subjek pada penelitian ini semuanya bersekolah d IUar lingkungan panti asuhan. Di sekolah, anak mempunyai kesempatan yang lebih luas untuk berinteraksi dengan orang-orang di luar panti, khususnya teman sebaya dan guru. Kesempatan tersebu: sangat penting bagi anak untuk belajar berbagai macam pola interaksi. Semakin banyak kesempatan yang diberikan pada anak untuk berinteraksi dengan teman sebayanya semakin banyak pengenalan terhadap berbagai macam pola interaksi dalam bertagai hubungan interpersonal. Hal tersebut dapat diartikan bahwa pengalaman berinteraksi anak bertambah banyak. Pengalaman tersebut akan menambah kemampuan anak dalam melakukan hubungan interpersonal yang efektif.

Dalam berinteraksi dengan teman sebaya, melalui reaksi teman terhadap dirinya, anak akan bisa menilai apakah dirinya dapat diterima oleh teman-ternan sebaya. Penilaian anak terhadap dirinya bahwa dia dapat diterima oleh lingkungannya dapat menimbulkan sikap yang positif, yaitu rasa percaya diri. Dengan rasa percaya diri anakakan lebih berani bereksplorasi. Semakin anak berani melakukan eksplorasi, semakin ber- 
tambah kemampuannya dalam membina hubungan interpersonal.

Faktor lain yang diperkirakan dapat mempengaruhi perkembangan tingkat kompetensi interpersonal anak adalah karakteristikanak. Sebagai makhluk individu, anak memiliki karakteristik yang khas, salah satunya adalah kepribadian. Anak dengan kepribadian terbuka (extrovert) akan memiliki karakteristik yang berbeda dengan anak yang tertutup (introvert).

Lingkungan fisik di luar lingkungan panti diperkirakan dapat mempengaruhi hasil penelitian ini. Panti asuhan sistem ibu asuh terletak di daerah yang terisolasi sedangkan panti asuhan sistem tradisional terletak di daerah yang padat.

\section{PENUTUP}

Simpulan penelitian ini adalah tidak ada perbedaan kompetensi interpersonal antara anak-anak panti asuhan yang diasuh dengan sistem pengasuhan tradisional dan anak-anak panti asuhan yang diasuh dengan sistem ibu asuh.

Adapun saran-saran yang hendak penulis ajukan adalah sebagai berikut. Bagi panti asuhan, penelitian ini belum dapat memberikan jawaban tentang sistem pengasuhan yang paling efektif untuk meningkatkan kompetensi interpersonal anak berhubung banyak sekali faktor yang diperkirakan memberikan pengaruh terhadap perkembangan tingkat kompetensi interpersonal yang udak diperhatikan. Oleh karena itu, bagi peneliti yang berminat untuk meneliti anak-anak panti asuhan, sebaiknya memperhatikan faktor-taktor:

1. Waktu. yaitu lamanya anak diasuh di panti asuhan.

2. Usia anak pada waktu mulai diasuh di panti asuhan.

3. Latarbelakang anak atau alasan penempatan anak di panti asuhan.
4. Kondisi psikologis anak, yaitu kepribadian dan kondisi mental yang lain.

5. Lingkungan fisik di sekitar panti asuhan.

Walaupun demikian, untuk panti asuhan sistem ibu asuh disarankan supaya memberikan kesempatan yang seluas-luasnya pada anak untuk berinteraksi dengan lingkungan sosial di luar panti asuhan. Kesempatan ini dapat membentu menghindari eksklusivitas, artinya anak memiliki perasaan bahwa mereka berbeda (lebih baik ataupun lebih buruk).

Untuk panti asuhan sistem tradisional, dengan keterbatasan waktu dalam berinteraksi (melihat dari jumiah anak yang diasuh) maka kualitas interaksi seyogyanya harus ditingkatkan. Kualitas interaksi di antaranya adalah ekspresi rasa sayang seperti sentuhan, tepukan halus, pelukan dari pengasuh dapat dilakukan untuk anak-anakasuh. Ekspresi rasa sayang ini dapat menimbulkan perasaan aman dan terlindung. 7

\section{DAFTAR PUSTAKA}

Alen. D.E. \& Edgley, J., 1980. Social PSychology as Social Process. Betmont: Woodworth Publishing Co.

Bee, H. 1981. The Developing Child, 3rd ed. New York: Hatper \& Row, Publishers Inc.

Buhrmester, Furman, Wittenberg \& Reis, 1988. Five Domains of Interpersonal Competence. Journal of Personality and Social Psychology, Vol 24, No. 1. 9911008.

Cahoun, J.F. \& Acocella, J.R. 1990. Psychology of Adjusment and Human Re. lationships, 3rd ed. New York: McGrawHill Publishing Company.

Erickson, M.T. 1978. Child Psychopathology. Englewood Clitfs, New Jersey: Prentice-Hail: inc. 
Grasha, A.F. 1987. Practical Application in Psychology. Illinios: The Dorcey Press Homewood.

Hill, C.A. 1991. Seeking Emotional Support: The intluence of Affiliative Need and Partner Warmth, Joumal of Personality and Social Psychology. Vol. 60, No. 1, 112.121.

Mussen, P.H. Conger J.J. \& Kagan J. 1979. Child Development and Personality. 5th ed. New York: Harper and Row Publishers, inc.

Newman, B.M. \& Newman, P.R. 1979. Development Through Life. Ilinois: The
Dorsey Press, Homewood.

Periman, D. \& Cozby, P.C. 1983. Social Psychology, New York: Holt, Rinehart \& Winston.

Winarto. 1990. Hubungan Antara Pola Asuh Orang Tua Demokratis dengan Kepribadian Wiraswasta pada Remaja Akhir, Skripsi Sarjana (tidak diterbitkan). Yog. yakarta: Fakultas Psikologi Universitas Gadjah Mada.

Wrightsman. L.S. \& Deaux. K.198t. Social Psychology in the "8os, 3rd ed. Monterry: Brooks/Cole Publishing Company. 